\title{
Selection of the Multiple-Criiater Decision-Making Method for Evaluation of Sustainable Energy Development: A Case Study of Poland
}

\author{
Małgorzata Trojanowska * and Krzysztof Nęcka \\ Faculty of Production and Power Engineering, University of Agriculture, 30-149 Kraków, Poland; \\ krzysztof.necka@urk.edu.pl \\ * Correspondence: malgorzata.trojanowska@urk.edu.pl; Tel.: +48-12-662-46-47
}

Received: 30 September 2020; Accepted: 25 November 2020; Published: 30 November 2020

check for updates

\begin{abstract}
One of the basic objectives of the European Union's energy policy is to obtain and use energy in a sustainable way. Multiple-criteria decision making (MCDM) methods, in particular linear ordering based on the synthetic variable procedure, are used for comparative analyses of the level of energy sustainability. Despite many studies, the problem of choosing the optimal ordering method is still not fully resolved. This paper presents an original procedure that facilitates the selection of an effective method of the linear ordering of multi-feature objects for the evaluation of sustainable energy development of regions. What is understood as the effective ordering of regions is not only the effective ranking of objects but also their effective clustering. In order to obtain the best results of linear ordering, the authors put forward a multi-stage optimization of the selection of the method of ordering and normalization of diagnostic variables. Analysis of variance was used for the assessment of the object ranking quality, while for the assessment of the object clustering quality, an innovative approach was presented based on the analysis of the empirical distribution of the frequency of occurrence of the distance between objects. The linear ordering method, selected on the basis of the procedure proposed in the paper, was used to assess the energy sustainability of Polish regions. The calculations and analyses were carried out using the set of indicators developed by the authors. They characterize the sustainable energy development of regions in the social, economic, and environmental dimensions.
\end{abstract}

Keywords: energy sustainability; MCDM; synthetic indicator; composite measure; SAW; TOPSIS; Hellwig method; WASPAS

\section{Introduction}

The cornerstone of the development of each society is economic growth. A crucial factor in this achievement is access to energy, which should be permanent and relatively harmless to the environment, as indicated by the principles of sustainable energy development. Sustainable energy development is not a solution that is competitive to the general principles of sustainable development but should rather be regarded as their expansion that takes into account the distinctive nature of energy management.

Though widely used, the concept of sustainable energy is still rather ambiguous. In an intuitive way, it is understood as obtaining energy in a method that is as little harm to the environment as possible, preferably from renewable sources, and increasing energy efficiency, while ensuring adequate energy security that takes into account the needs of the present and future generations, as well as social, economic, and environmental aspects of human development.

Sustainable energy development is one of the basic objectives of the European Union's (EU) energy policy. It assumes reducing greenhouse gas emissions by at least $40 \%$, a $32 \%$ share of renewable energy 
sources (RESs) in the overall balance of energy consumption in the EU, and increasing the EU energy efficiency by at least $32.5 \%$ by 2030 [1].

Implementation of the concept of sustainable energy requires an evaluation of the progress and differences in this regard. In order to evaluate compliance of energy development with the objectives defined by the European Union, appropriate indicators are required. Various international and national institutions have been trying to work out a solution for years. One of the first significant works on energy indicators for sustainable development was published by the International Atomic Energy Association (IAEA) [2]. Energy indicators are also described in the publications of such European authorities and agencies as Eurostat [3], the International Energy Agency [4], Renewable Energy Policy Network for the 21st Century (REN21) [5], and International Renewable Energy Agency (IRENA) [6], as well as in statistics of individual states. In addition, many researchers have been putting forward their own suggestions in this area, either referring to the above-mentioned studies and documents or by creating their own databases $[7,8]$.

The main objective of all these works is to come up with reliable indicators that would characterize energy in the sustainable development model. However, they cannot be regarded as a set of indicators for monitoring sustainable energy development by themselves. The need for such a set of indicators has been repeatedly mentioned [9-11], and although the scope of collected statistical data that can be used to describe sustainable energy development is constantly expanding, it is still insufficient, especially in terms of regional and local energy management $[8,12-14]$.

Sustainable energy development can be evaluated from various perspectives, such as the potential of renewable sources, energy efficiency, or energy security [12,15-18]. One can also attempt to take into account all the factors that define sustainable energy simultaneously. Each of the above-mentioned issues is a complex problem that usually requires multi-feature characteristics.

The selected diagnostic variables can be examined individually or after aggregation using multiple-criteria decision making (MCDM). The use of MCDM methods in energy sustainability analyses is growing rapidly [19]. Their use in solving RES problems is also growing, which, in addition to energy efficiency, constitutes a fundamental pillar of energy sustainability $[20,21]$.

MCDM methods, in particular linear ordering based on the synthetic variable procedure, are often used in sustainability analysis at the national and regional level, mainly to support policy-makers.

Most of the multi-criteria problems are solved by arbitrarily selected methods. However, different methods of normalization, weighting, and aggregation of data often give significantly different results when solving the same decision problem. In the literature on the subject, this problem receives a lot of attention, especially in relation to the normalization of criteria. Criteria normalization is an essential part of any decision-making process as it transforms input data into numerical and comparable data, allowing the use of MCDM methods to evaluate and rank alternatives. Many techniques for data normalization have been proposed. In their work, Jahan and Edwards [22] identified 31 normalization methods, classified them, and described the basic advantages and disadvantages of each of them within the framework of engineering design. The conducted research shows that although the normalization of data affects the obtained results, it is difficult to determine which method of normalization obtains the best results.

Many authors believe that it depends primarily on the MCDM method used, hence a number of studies concern the search for the best techniques of normalization within particular methods. Chakraborty and Yeh [23] analyzed four normalization techniques (vector and 3 linear) as part of solving problems with the Simple Additive Weighting (SAW) method. They used the ranked consistency index (RCI) to evaluate the techniques. Similar studies for only six methods were carried out by Vafaei et al. [24]. Celen [25] analyzed the effect of vector normalization and three linear normalizations in the Technique for Order of Preference by Similarity to Ideal Solution (TOPSIS) method. According to his calculations, based on the Pearson correlation coefficient, the most appropriate normalization for the TOPSIS method is vector normalization. Vafaei et al. [26] assessed the usefulness of four types of normalization for the TOPSIS method, i.e., vector, linear, logarithmic, and fuzzy, 
using the RCI measure, the Pearson correlation coefficient, and the Spearman correlation coefficient. They considered vector normalization the best and log normalization the worst. They performed similar analyses in relation to the AHP method [27]. Vector normalization was also considered the best by Chatterjee and Chakraborty [28], carrying out calculations within the following methods: Promethe II, GRA, and TOPSIS. For the comparative assessment, they used Kendal's compatibility factor and the Spearman correlation coefficient. They found that the Promethe II method is resistant to a change in the normalization method, and the TOPSIS method is very sensitive. Zaidan and Zaidan [29] recommended linear normalization for the TOPSIS method. Pavlicic [30] checked the effects of linear and vector normalization using the simulation method using the SAW, TOPSIS, and ELETRE methods. He showed that even the unit of the included input variable can influence the calculation results. Wiecckowski and Sałabun [31] investigated the impact of the data normalization technique on decisions made using the VIKOR method. A comprehensive approach to normalization issues in classification processes was presented by Jain et al. [32]. They developed 14 classification models using various learning algorithms to dynamically select the normalization technique using data complexity measures.

Part of the works concerns the comparison of decisions resulting from the use of different MCDM methods for specific standardization methods. Opricovic and Tzeng [33] compared the results obtained with the VIKOR method for linear normalization and the TOPSIS method for vector normalization of variables. Papathanasiou et al. [34] presented the implementation of an internet decision support system enabling comparisons between the rankings obtained with the TOPSIS and VIKOR methods, and at the same time helping in the selection of the normalization technique using data complexity measures. Bak [35] compared the ordering of objects using the Hellwig method using variable standardization and the TOPSIS method using vector normalization using empirical and simulation data. He used the quality measures of linear ordering procedures to compare the methods [36]. The research results obtained by Roszko-Wójtowicz and Grzelak [37] also confirmed that the applied method of linear ordering and the selection of the normalization procedure has an impact on the final ranking of the examined objects. The authors tested the Hellwig method, the TOPSIS method, and the GDM method while normalizing the variables with three methods. Ceballos et al. [38] compared the rankings of objects obtained using the MULTIMOORA, TOPSIS, and VIKOR methods based on 1600 randomly generated decision problems. They used the Spearman correlation coefficient for the assessment. A lot of works are devoted to the choice of criteria weighting [39-44]. MCDM methods use both weighting criteria: the equal weights and the rank-order weights. A broad overview of the MCDM criteria weighting methods can be found in the work by Jiangiiang et al. [20].

As can be seen from the above-cited works, the selection of procedures appropriate to solve a specific decision problem is difficult and is still a scientific problem. As early as the 1980s, Gershon [45] and Tecle [46] developed models to support the selection of the MCDM method. Since then, the difficulty of choosing has increased as many new methods have emerged [47]. In addition to methodological works aimed at supporting the selection of optimal methods, there are also works in which the effects of the method and initial data processing on the result of a specific decision problem are minimized. In addition to using various types of metrics for this purpose [48-53], one method is selected based on the analysis of the advantages and disadvantages of several methods, or the problem is solved with several methods to make decisions more convincing [48,54-56]. For the purposes of selecting the MCDM method and methods of data pre-processing, various matrixes are also proposed to support this choice $[23,25,32,57-61]$ or new linear ordering procedures are developed which, according to its authors, give better ranking results $[10,48,60,62-65]$.

It is expected that the applied methods and procedures of linear ordering take into account the nature of the ordered objects. In general, linear ordering consists of arranging objects from the best to the worst one according to the adopted criterion, when object clustering is of secondary importance. However, in the evaluation of energy sustainability, it is also important to properly classify objects into mutually disjoint and exhaustive subsets. 
The objective of this research was to select methods and tools for the linear ordering of multi-feature objects for the purposes of evaluation of regional sustainable energy development that would ensure not only effective ranking of objects but also the determination of clusters of homogeneous objects. The latter problem has not been solved so far, and it concerns an important issue of sustainable energy, i.e., the proper definition of development types. The research objective was achieved through the development of a procedure facilitating the selection of the method of linear object ordering.

This procedure was used to test the research hypothesis that the quality of linear ordering is influenced not only by the adopted method of determining synthetic variables and variable normalization but also by the method of converting variables determined on the basis of their minimization (destimulants) into normalized values based on the maximization of the variables (stimulants).

The scope of the work also included the development of a set of indicators characterizing sustainable energy development at the regional level, based on data available in the public statistics of Poland.

\section{Research Method}

The MCDM problem in the field of sustainable energy can be presented as a decision matrix:

$$
\begin{aligned}
& \text { criteria } C_{1} C_{2} \ldots C_{n} \\
& \text { (weights } w_{1} w_{2} \ldots w_{n} \text { ) }
\end{aligned}
$$

alternatives

$$
\mathrm{X}=\begin{gathered}
A_{1} \\
A_{2} \\
\vdots \\
A_{m}
\end{gathered}\left(\begin{array}{cccc}
x_{11} & x_{12} & \cdots & x_{1 n} \\
x_{21} & x_{22} & \cdots & x_{2 n} \\
\vdots & \vdots & \ddots & \vdots \\
x_{m 1} & x_{m 2} & \cdots & x_{m n}
\end{array}\right)_{m \times n}
$$

where $x_{i j}$ is the performance of $j$-th criterion (diagnostic variable) of $i$-th alternative (object, region), $w_{j}$ is the weight of $j$-th criterion, $n$ is the number of criteria and $m$ is the number of alternatives.

The general framework for the evaluation of linear ordering methods and data pre-processing methods are as follows:

1. Identyfication of criteria:

- substantive selection,

- formal and statistical selection,

- determining property.

2. Preprocessing of data:

- determination the weights of criteria,

- conditional conversion of destimulants into stimulants,

- normalization of criteria.

3. Aggregation of criteria.

4. Evaluation of normalization and aggregation methods based on:

- similarities of synthetic variables to diagnostic variables,

- ranking quality by ANOVA,

- clustering quality using empirical distributors.

5. Analysis of the sensitivity of decision solutions.

The flowchart that presents the procedure of determining synthetic variables describing sustainable energy development is presented in Figure 1. 


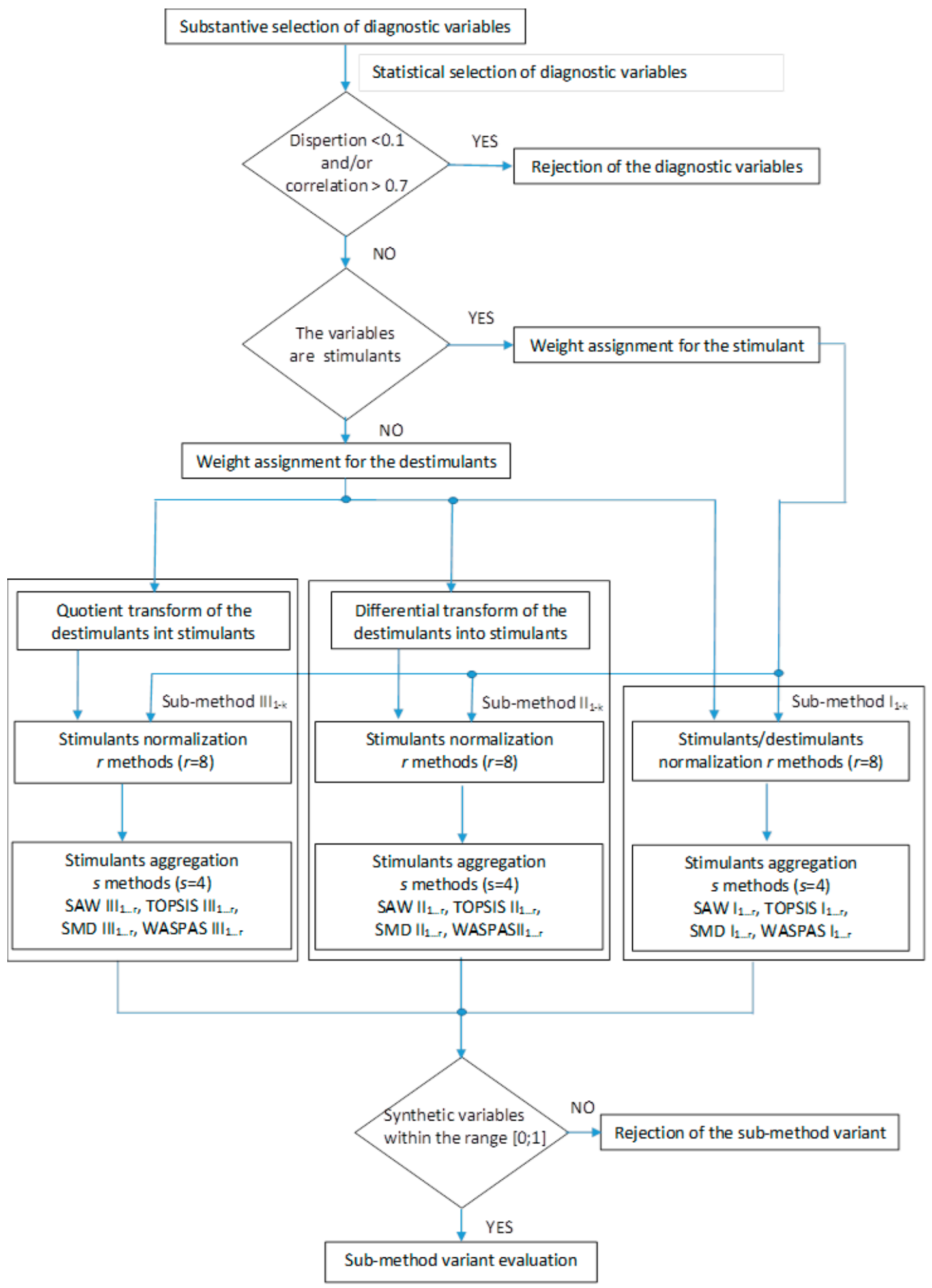

Figure 1. Procedure of synthetic variables selection.

\subsection{Identification of Criteria}

Properly conducted selection of diagnostic variables should include substantive and formal-statistical selection. Within the framework of the substantive criterion, indicators related to the field, scope, and type of research are established, and which do not depend on the research technique. They should be strictly defined, unambiguous, representing as well as possible the phenomena and processes included in the scope of the study, and at the same time universally. According to the formal-statistical criterion, 
the indicators are to be measurable and complete, well-discriminate against objects, be poorly correlated with each other, and strongly correlated with rejected characteristics.

The set of diagnostic indicators was established based on the data available in the statistics of Polish regions [66]. The detailed description is provided in Section 3.1.

The selected indicators were subject to statistical selection in terms of:

- dispersion, rejecting the variables for which the standard coefficient of variation was below 0.1,

- correlation, taking into account only features that are weakly correlated with one another (Pearson's correlation coefficient of less than 0.7 ).

The variables used to describe the objects may be of different nature due to the impact on the examined criteria. Hence, there are stimulants, destimulants, and nominants. The indicators used in the study have either a positive effect (stimulants) or a negative effect (destimulants).

\subsection{Preprocessing of Data}

In the study, equal weights of criteria were adopted i.e., $w_{j}=\frac{1}{n}, \sum_{j=1}^{n} w_{j}=1$. Many authors attach different weights to the criteria, perceiving it as an improvement in inference [39-41]. There are also those who believe that adopting equal weights of criteria may be the best solution according to the medical principle of primum non nocere [42-44]. The authors of the work assumed equal weights of variables describing sustainable energy development at the regional level, as they believe that proper determination of weights with constraints related to obtaining data from public statistics is very difficult, and in addition, involuntary weighing may occur.

Conversion of destimulants into stimulants was carried out in a twofold manner:

- during normalization (using minimizing normalization),

- before normalization, by stimulating the destimulants by means of a differential transform:

$$
x_{i j}:=\max _{i}\left(x_{i j}\right)-x_{i j}
$$

- before normalization, by stimulating the destimulants by means of a quotient transform:

$$
x_{i j}:=\frac{1}{x_{i j}}
$$

In the paper, recognized normalization formulas were adopted, although those that eliminate the variability of normalized values (e.g., classical or positional standardization) were excluded, which gave in total 8 standardization methods. All of them are presented in Table 1.

\subsection{Aggregation of Criteria}

Four methods were selected for the research:

- $\quad$ Simple Additive Weighting (SAW),

- Technique for Order of Preference by Similarity to Ideal Solution (TOPSIS),

- The synthetic measure of development (SMD),

- Weighted Aggregated Sum Product Assessment (WASPAS).

The SAW method was first presented in 1954 by Churchman and Ackoff [75]. With time, it became one of the best-known algorithms for multi-criteria analysis, mainly due to its intuitiveness and the simplicity of determining synthetic variables. The value of the synthetic variable is determined from the relationship:

$$
q_{i}=\frac{1}{n} \sum_{j=1}^{n}\left(x_{i j}^{*}\right)
$$


Table 1. Normalization methods of diagnostic variables.

\begin{tabular}{|c|c|c|c|}
\hline \multirow{2}{*}{$\begin{array}{l}\text { Designation } \\
\text { of the Method }\end{array}$} & \multirow[b]{2}{*}{ Normalization Method } & \multicolumn{2}{|c|}{ Formula } \\
\hline & & $\begin{array}{l}\text { Normalization of } \\
\text { Stimulants }\end{array}$ & $\begin{array}{c}\text { Normalization of } \\
\text { Destimulants }\end{array}$ \\
\hline 1 & Van Delftand Nijkamp [67] & $x_{i j}^{*}=\frac{x_{i j}}{\sqrt{\sum_{i=1}^{m} x_{i j}^{2}}}$ & $x_{i j}^{*}=1-\frac{x_{i j}}{\sqrt{\sum_{i=1}^{m} x_{i j}^{2}}}$ \\
\hline 2 & Weitendorf [68] & $x_{i j}^{*}=\frac{x_{i j}-x_{j}^{-}}{x_{j}^{+}-x_{j}^{-}}$ & $x_{i j}^{*}=\frac{x_{j}^{+}-x_{i j}}{x_{j}^{+}-x_{j}^{-}}$ \\
\hline 3 & Peldschus [69] & $x_{i j}^{*}=\left(\frac{x_{i j}}{x_{j}^{+}}\right)^{2}$ & $x_{i j}^{*}=\left(\frac{x_{j}^{-}}{x_{i j}}\right)^{3}$ \\
\hline 4 & Jüttler [70] & $x_{i j}^{*}=\frac{x_{j}^{+}-x_{i j}}{x_{i j}^{+}}$ & $x_{i j}^{*}=\frac{x_{j}^{-}-x_{i j}}{x_{i j}^{-}}$ \\
\hline 5 & Körth [71] & $x_{i j}^{*}=1-\left|\frac{x_{j}^{+}-x_{i j}}{x_{j}^{+}}\right|$ & $x_{i j}^{*}=1-\left|\frac{x_{j}^{-}-x_{i j}}{x_{j}^{-}}\right|$ \\
\hline 6 & Stopp [72] & $x_{i j}^{*}=\frac{100 \cdot x_{i j}}{x_{j}^{+}}$ & $x_{i j}^{*}=\frac{100 \cdot x_{j}^{-}}{x_{i j}}$ \\
\hline 7 & Voodg [73] & $x_{i j}^{*}=\frac{x_{i j}}{\sum_{i=1}^{m} x_{i j}}$ & $x_{i j}^{*}=1-\frac{x_{i j}}{\sum_{i=1}^{m} x_{i j}}$ \\
\hline 8 & Logarithmic [74] & $x_{i j}^{*}=\frac{\ln \left(x_{i j}\right)}{\ln \left(\prod_{i=1}^{m} x_{i j}\right)}$ & $x_{i j}^{*}=\frac{1-\frac{\ln \left(x_{i j}\right)}{\ln \left(\Pi_{i=1}^{m} x_{i j}\right)}}{m-1}$ \\
\hline
\end{tabular}

Where: $x_{i j}^{*}$-normalized value of the $i$-th alternative according to the $j$-th criterion, $x_{j}^{+}=\max _{i}\left(x_{i j}\right), x_{j}^{-}=\min _{i}\left(x_{i j}\right)-\operatorname{maximum}$ or minimum value of the $i$-th alternative according to the $j$-th criterion.

An equally popular and convenient method used for multi-criteria decision making is the TOPSIS algorithm proposed by Hwang and Yoon [76,77]. The construction of a synthetic variable consists of the following steps:

- determination of pattern coordinates: $z_{o j}^{+}=\max _{i}\left\{x_{i j}^{*}\right\}$

- determining the coordinates of the anti-pattern: $z_{o j}^{-}=\min i\left\{x_{i j}^{*}\right\}$

- determining the distance of objects from the pattern:

$$
d_{i o}^{+}=\sqrt{\sum_{j=1}^{n}\left(x_{i j}^{*}-z_{o j}^{+}\right)^{2}}
$$

- determining the distance of objects from the anti-pattern:

$$
d_{i o}^{-}=\sqrt{\sum_{j=1}^{n}\left(x_{i j}^{*}-z_{o j}^{-}\right)^{2}}
$$

- determining the value of an aggregate variable:

$$
q_{i}=\frac{d_{i o}^{-}}{d_{i o}^{+}+d_{i o}^{-}}
$$

Another MCDM method analyzed in the paper is the method of linear ordering, based on the synthetic measure of development (SMD), which is very popular in Poland. The author of this method is Hellwig, one of the precursors of MCDA methods. The algorithm of the method was described in 1968 in his work [78], and it is as follows: 
- determination of pattern coordinates:

$$
z_{j o}=\max _{i}\left\{x_{i j}^{*}\right\}
$$

- determining the distance of objects from the pattern:

$$
d_{i o}=\sqrt{\sum_{j=1}^{n}\left(x_{i j}^{*}-z_{o j}\right)^{2}}
$$

- determining the value of a synthetic variable:

$$
q_{i}=1-\frac{d_{i o}}{d_{o}}
$$

where:

$$
\begin{gathered}
d_{o}=\bar{d}_{o}+2 \cdot s_{d} \\
\bar{d}_{o}=\frac{1}{m} \sum_{i=1}^{m} d_{i o} \\
s_{d}=\sqrt{\frac{1}{n} \sum_{i=1}^{m}\left(d_{i o}-\bar{d}_{o}\right)^{2}}
\end{gathered}
$$

In addition to the aforementioned three standard discrete MCDM methods, the fourth method used in the paper for analysis was the recently developed but increasingly popular WASPAS technique [79]. The method was designed in order to increase ranking accuracy in the event of conflicting criteria, which may occur also in analyses related to energy sustainability. The determination of the synthetic variable is as follows:

$$
q_{i}=0.5 \cdot q_{i}^{(1)}+0.5 \cdot q_{i}^{(2)}
$$

where:

$$
\begin{gathered}
q_{i}^{(1)}=\sum_{j=1}^{n} x_{i j}^{*} \cdot \frac{1}{n} \\
q_{i}^{(2)}=\prod_{j=1}^{n}\left(x_{i j}^{*}\right)^{\frac{1}{n}}
\end{gathered}
$$

The patterns (3)-(15) were given assuming equal weights of criteria. Each method assumes that $\max _{i}\left\{q_{i}\right\}$ corresponds to the best objec and $\min _{i}\left\{q_{i}\right\}$ 一the worst object.

Because the destimulants were stimulated in three different ways in each of the methods and the variables were normalized with 8 methods, 96 methodological variants were obtained, called sub-methods. The calculations were made for all dimensions of sustainable development. A total of 288 decision matrices were built.

For each of the variants, synthetic indices were determined, but further analysis involved only those in which all synthetic variables describing the regions were within the range $[0,1]$.

\subsection{Evaluation of Normalization and Aggregation METHODS}

Many authors believe that the usefulness of a particular criteria normalization technique depends to a large extent on the MCDM method used. Hence, in the paper, the methods of normalization of diagnostic variables within each of the sub-methods were initially assessed.

The adopted measures were taken from Grabiński et al. [36]. They determine the linear correlation of the synthetic variable with the diagnostic variables (measures $M 1$ and M2), the rank correlation of 
the synthetic variable with the diagnostic variables (measures $M 3, M 4, M 5$ ), and the variability and concentration of the synthetic variable (measures M6 and M7), determined from the following formulas:

$$
\begin{aligned}
& M 1=1-\frac{1}{n} \sum_{j=1}^{n} r_{j} \\
& M 2=\frac{1}{n} \sum_{j=1}^{n} l\left(r_{j}\right)
\end{aligned}
$$

where:

$r_{j}$-correlation coefficient between the $j$-th diagnostic variable and the synthetic variable, $n$-number of variables.

$$
\begin{gathered}
l\left(r_{j}\right)=\left\{\begin{array}{r}
0 \text { for } r_{j} \in[0.5 ; 1], \\
1 \text { for } r_{j} \in[0 ; 0.5], \\
2 \text { for } r_{j} \in[-0.5 ; 0], \\
3 \text { for } r_{j} \in[-1 ;-0.5] .
\end{array}\right. \\
M 3=1-\frac{1}{n} \sum_{j=1}^{n} \rho_{j}
\end{gathered}
$$

where:

$\rho_{j}$-rank correlation coefficient between $j$-th diagnostic variable and the synthetic variable,

$$
l\left(\rho_{j}\right)=\left\{\begin{array}{c}
0 \text { for } \rho_{j} \in[0.5 ; 1], \\
1 \text { for } \rho_{j} \in[0 ; 0.5], \\
2 \text { for } \rho_{j} \in[-0.5 ; 0] \\
3 \text { for } \rho_{j} \in[-1 ;-0.5] .
\end{array}\right.
$$

$\dot{x}_{i j}$-the rank of the $i$-th object with respect to the $j$-th diagnostic variable, $\dot{q}_{i}$-the rank of the $i$-th object with respect to the $i$-th synthetic variable.

$$
\begin{aligned}
& l=\left\{\begin{array}{c}
n^{2} \text { for even } n \text { numbers, } \\
n^{2}-1 \text { for odd } n \text { numbers. }
\end{array}\right. \\
& M 6=-\frac{s_{m}}{\bar{m}} \\
& M 7=\frac{S_{\Delta}}{\bar{\Delta}}
\end{aligned}
$$

where:

$\bar{m}, s_{m}$-mean and standard deviation of the synthetic variable,

$\bar{\Delta}, S_{\Delta}$-mean and standard deviation of $\Delta_{k}=\widetilde{m}_{k}-\widetilde{m}_{k-1}$,

where $\widetilde{m}_{k}$ are implementations of the synthetic variable in non-decreasing order, $k=1,2, \ldots, m$. 
Since the partial measures $M 1, \ldots, M 7$ have an unambiguous direction of preference-smaller numerical values of each measure indicate a better quality of mapping diagnostic variables with synthetic variables-their aggregation was performed according to the formula:

$$
M=\sqrt{\sum_{l=1}^{g} M_{l}^{2}}
$$

where:

$M$-aggregate measure of the quality of mapping diagnostic variables with synthetic variables of the linear ordering sub-method,

$M_{l}$-partial measure of the quality of mapping diagnostic variables with the synthetic variable of the linear ordering sub-method $(l=1,2, \ldots, g)$,

$g$-number of partial measures.

The $M$ meter was the basis for the selection of effective methods of normalizing diagnostic variables within each of the sub-methods.

In order to evaluate the quality of ranking, the measure proposed by Kukuła and Luty [57] was adopted, which is represented by the following formula:

$$
u_{p}=\frac{1}{v-1} \sum_{\substack{q=1 \\ p \neq q}}^{v} m_{p q}, \quad p, q=1,2, \ldots, v
$$

based on the similarity of rankings

$$
m_{p q}=1-\frac{2 \sum_{i=1}^{m}\left|c_{i p}-c_{i q}\right|}{m^{2}-z}
$$

where:

$c_{i p}$-position of the $i$-th object in the ranking with the number $p$,

$c_{i q}$-position of the $i$-th object in the ranking with the number $q$,

$$
z=\left\{\begin{array}{c}
0, m \in P \\
1, m \notin P
\end{array} \text { and } P-\right.\text { a set of even natural numbers. }
$$

The measure $m_{p q} \in[0,1]$ is used for inter-rank comparisons, each with each. The results of all inter-rank comparisons can be presented in a symmetrical $N$ matrix with dimensions $(v \times v)$, where $v$ is the number of rankings, $m_{p q}=1$ when $p=q$.

$$
N=\left[m_{p q}\right]=\left(\begin{array}{ccccc}
1 & m_{12} & m_{13} & \cdots & m_{1 v} \\
m_{21} & 1 & m_{23} & \cdots & m_{2 v} \\
\vdots & \vdots & \vdots & \vdots & \vdots \\
\vdots & \vdots & \vdots & \vdots & \vdots \\
m_{v 1} & m_{v 2} & m_{v 3} & \cdots & 1
\end{array}\right)
$$

In order to determine the degree of similarity of the ranking obtained as a result of the application of the $p$-th method of linear ordering in relation to the other rankings, the sum of the $p$ elements of the row of the $N$ matrix (Formula (24)) minus 1 should be calculated. 
For the methods considered to ensure the best quality of ranking of objects, empirical distributions were developed, showing the frequencies of distances between objects, supporting the decision making regarding the selection of a method that also ensures the effective determination of object clusters.

\subsection{Sensitivity Analysis}

In order to assess the usefulness of the proposed procedure for selecting the method and tools for the linear ordering of objects, an analysis of the sensitivity of decision solutions to the change in the values of the adopted criteria was carried out, which is described in Section 3.3.

The ordering method, selected on the basis of the procedure proposed in the paper, was finally used to analyze the sustainable energy development of the regions on the example of Poland.

\section{Research Results}

\subsection{Selection of Diagnostic Variables}

Evaluation of sustainable energy development at the regional level is important, for instance in terms of the cohesion policy or various support schemes related to the energy sector. Unfortunately, only a small percentage of the data currently available in public statistics that could be used for such an evaluation is useful. Based on the data available in the statistics of Polish regions [66], 44 operational indicators were selected which, according to the authors, meet the substantive criterion. After taking into account the formal and statistical criteria, the number of indicators was reduced to 13. The major reason for rejecting such a large number of diagnostic variables was their high mutual linear correlation.

Sustainability of development, including energy, is a state of balance between at least three of its dimensions: social, economic, and environmental. Each of these dimensions requires an appropriate set of indicators. Extensive criticism of them can be found in the paper of Gunnars et al. [12]. They assessed 57 sets of energy sustainability indicators and concluded that they need further improvement. This problem is also addressed by Kemmler and Spreng [80] who stressed that grouping the indicators is a difficult task due to the dependence and interdependence of the different dimensions of sustainability. In the literature on the subject, attention is drawn to the possibility of classifying indicators in more than one dimension and it is recommended that when selecting indicators of sustainable development, if possible, to integrate the dimensions by indicators relating to more than one dimension $[2,6,81]$.

\subsubsection{Social Dimension}

The social dimension of sustainable energy development has many aspects and almost all of them depend on the availability of energy. The availability of energy directly affects educational opportunities, employment, and poverty. The availability of energy is not only its affordability but also a guarantee of energy supply. Therefore, it was considered that the social dimension should include, in addition to the electricity consumption indicator, the so-called consumption pattern and the indicator describing the affordability of energy, also an indicator describing energy security. The impact of energy production and use on human health is also taken into account (Table 2).

Table 2. Sustainable energy development indicators in the social dimension.

\begin{tabular}{cccc}
\hline Criterion & Indicator & Unit & Designation \\
\hline Consumption pattern & Electricity consumption per capita & $\mathrm{kWh} / \mathrm{cap}$ & $\mathrm{X}_{1}$ \\
\hline Energy affordability & HC-LI ratio & $\%$ & $\mathrm{X}_{2}$ \\
\hline Energy security & $\begin{array}{c}\text { The ratio of electricity production to } \\
\text { electricity consumption }\end{array}$ & $\%$ & $\mathrm{X}_{3}$ \\
\hline Health & $\begin{array}{c}\text { Total emission of air pollutants from } \\
\text { particularly polluting plants per capita }\end{array}$ & $\mathrm{t} / \mathrm{cap}$ & $\mathrm{X}_{4}$ \\
\hline
\end{tabular}


The most important indicator for monitoring consumption is household electricity consumption per capita. This is a common variable used in sustainability analyses and this variable has also been used in the work to assess social sustainability. Unit electricity consumption is treated as a measure of well-being, especially in relation to developing countries.

Another very important factor is the affordability of energy. Relatively expensive energy places an excessive burden on household budgets and discourages entrepreneurship and investment. The High Cost-Low Incom ratio (HC-LI) [66] was used to assess energy affordability, which is based on the assumption that a household can be considered energy poor if it has low income and high hypothetical energy expenditure (expenditure that fully meets standard energy needs).

Sustainable development is not possible without a secure energy supply. The social aspect of energy security is the security of everyday life and, above all, job security. To assess the social aspect of energy security, information on the differences between energy supply and demand [81] is needed.

In the regional statistics [66], such information is available only for electricity, and in particular, it is an indicator expressing in percentage terms the degree to which electricity production in the region meets demand. Local energy generation, especially from renewable sources, can offer a number of social benefits: generate jobs by reducing unemployment, reduce the cost of energy by reducing energy poverty, and thus increase opportunities for regional development.

The last social indicator characterizes the impact of energy on human health through air pollution. Taking into account this impact in the social dimension was recommended in the study by Vera et al. [81]. The use of non-renewable energy sources is associated, on the one hand, with their long-term deficit and, on the other hand, represents a significant burden on the environment through the emission of pollutants. Environmental pollution directly affects people's health and lives, and therefore the inclusion of a unit air pollutant emission index in the social dimension seems to be fully justified.

\subsubsection{Economic Dimension}

The constant increase in the population and standard of living and the growing demand for energy generated by economic development is becoming a challenge for sustainable development. On the one hand, we have growing energy needs of the population and, on the other, we are striving to save energy and protect the environment. Combining these two processes is possible through intelligent control of energy consumption. However, the implementation of this process requires information on the amount of energy consumption and the current structure of consumption of individual carriers. In this work, the assessment of the economic sustainability of energy was made on the basis of indicators allowing for the assessment of unit energy consumption and the structure of consumed energy carriers (Table 3).

Table 3. Sustainable energy development indicators in the economic dimension.

\begin{tabular}{cccc}
\hline Criterion & \multicolumn{1}{c}{ Indicator } & Unit & Designation \\
\hline \multirow{3}{*}{$\begin{array}{c}\text { Energy efficiency-production } \\
\text { and use patterns }\end{array}$} & Energy consumption per capita & $\mathrm{kWh} / \mathrm{cap}$ & $\mathrm{X}_{5}$ \\
\cline { 2 - 4 } & $\begin{array}{c}\text { Total electricity consumption per } 1 \\
\text { million PLN of GDP }\end{array}$ & $\begin{array}{c}\text { GWh/1 } \\
\text { million PLN } \\
\text { of GDP }\end{array}$ & $\mathrm{X}_{6}$ \\
\cline { 2 - 4 } & Gas consumption per capita & $\mathrm{m}^{3} / \mathrm{cap}$ & $\mathrm{X}_{7}$ \\
\cline { 2 - 4 } $\begin{array}{c}\text { Energy efficiency-energy } \\
\text { saving }\end{array}$ & Energy-saving expenditure per capita & $\mathrm{t} / \mathrm{cap}$ & $\mathrm{X}_{8}$ \\
\hline
\end{tabular}

The leading indicator in the aspect of sustainable economic development is the real GDP per capita. Gross domestic product (GDP) is the basic measure of economic development, which in a synthetic form presents the most complete picture of the national economy and changes in economic structure. GDP per capita is therefore a very important indicator of the level of economic development, and its 
long-term growth is the main objective of the state's economic policy. If, however, we are talking about energy sustainability, the leading indicator may be total electricity consumption per million PLN of GDP. Electricity consumption is the main indicator for monitoring consumption patterns.

The Polish economy is still dominated by the consumption of coal as a primary energy carrier. Combustion of fossil fuels is connected with their long-term deficit and emission of harmful pollutants into the atmosphere. It is therefore advisable to take all measures aimed at reducing the consumption of coal for energy purposes and replacing it with ecological energy sources. The development of renewable energy sources does not yet allow the complete elimination of fossil fuels. Initiatives promoting the use of natural gas as a source of energy that generates less pollution are therefore desirable. These reasons have led the authors to use the indicator describing the consumption of natural gas and hard coal in the examined regions in the assessment of sustainability.

The depletion of reserves of fossil raw materials, coal, oil, and natural gas on the ground, as well as the increase in pollutant emissions, requires the economical handling of these resources in order to maintain the possibility of using this raw material base on the ground as long as possible, including for future generations. The key issue, therefore, is act to use them rationally. The level of expenditure on energy saving has therefore been used as an indicator for assessing sustainable energy development in economic terms. On the one hand, energy-saving makes it possible to extend the availability of conventional energy sources and, on the other, it also makes it possible to reduce emissions of pollutants.

\subsubsection{Environmental Dimension}

Environmental sustainability is assessed and interpreted differently. In most cases, however, it can be said to be about living and doing business within the limits of environmental resources. Most often, however, it is associated with limiting the negative impact of man and his activities on the natural environment. Therefore, it mainly concerns the problem of reduction of environmental pollution or at least not the deterioration of its current state by using e.g., RESs.

Bearing in mind the aforementioned requirements, a set of four key indicators representing the environmental dimension of sustainable development was selected for further analysis (Table 4).

Table 4. Sustainable energy development indicators in the environmental dimension.

\begin{tabular}{cccc}
\hline Criterion & Indicator & Unit & Designation \\
\hline \multirow{2}{*}{$\begin{array}{c}\text { Expenditure on } \\
\text { environmental protection }\end{array}$} & $\begin{array}{c}\text { Total expenditure on pollution } \\
\text { prevention per capita }\end{array}$ & PLN/cap & $\mathrm{X}_{10}$ \\
\cline { 2 - 4 } Renewable energy & $\begin{array}{c}\text { Total expenditure on pollution } \\
\text { reduction per capita }\end{array}$ & PLN/cap & $\mathrm{X}_{11}$ \\
\hline & $\begin{array}{c}\text { Share of energy from hydropower } \\
\text { plants and renewable fuels in total } \\
\text { electricity production }\end{array}$ & $\%$ & $\mathrm{X}_{12}$ \\
\cline { 2 - 4 } & Installed capacity in RESs per capita & W/cap & $\mathrm{X}_{13}$ \\
\hline
\end{tabular}

Actions taken to reduce environmental pollution must be implemented in a multi-faceted manner. The scope of corrective actions undertaken depends largely on local economic and technical conditions. In this paper, the assessment of actions aimed at reducing pollution emissions is carried out in two ways.

In the first one, two available indicators were used at the local level in Poland, i.e., expenditure on prevention and pollution reduction, which differentiated well from one region to another. Human activity in the field of energy generation is closely linked to the emission of pollutants. The extraction of energy from fossil fuels, which in Polish conditions prevail, results in local generation of pollution. Air pollution by solid particles and gases such as $\mathrm{CO}_{2}, \mathrm{CO}, \mathrm{SO}_{2}$, or $\mathrm{NO}_{\mathrm{x}}$ is particularly onerous. The degree of danger to human health and life depends, among other things, on the size of the pollution and the chemical composition of the air we all breathe. Unfortunately, however, the pollution produced locally as a result of atmospheric factors moves, widening the range of harmful 
effects. In addition, these pollutants penetrate our body together with food that comes into contact with the air during its production. Initiatives taken to reduce pollution are therefore one of the main indicators for assessing the degree of sustainability of energy development. This is confirmed by the fact that this indicator is often used in such analyses [82,83]. It is not possible to make a one-off change in the consumption structure of energy carriers. Therefore, long-term measures are necessary to reduce pollution in this area. The indicators used in the analysis make it possible to assess how much money is spent by individual regions on pollution prevention and reduction.

The second action in the field of environmental protection is initiatives aimed at increasing the use of low-emission systems using renewable energy sources. Two available indicators were used in the work. The first one is the power installed in RESs per person. This indicator allows us to assess to what extent a given region uses the available energy potential to reduce the emission of pollutants. Moreover, this indicator assesses the production potential of the region in the long term. Unfortunately, the information about installed capacity alone does not fully describe the degree of energy sustainability of the region, due to the fact that the reduction of pollutant emissions is mainly caused by the replacement of fossil energy with renewable energy. Therefore, in the study, it was decided to use the indicator of the share of energy from hydroelectric power plants and RESs in total electricity production.

The values of the substantively and formally-statistically selected indicators are presented in Table 5, and their basic characteristics are presented in Table 6.

\subsection{Selection of Linear Ordering Method}

If benchmarking is carried out with more methods of standardizing criteria, attempts may be made to limit their number to the most efficient ones. In the work for this purpose, the aggregation meter $\mathrm{M}$ was used to assess the mapping of diagnostic variables by synthetic variables.

Based on the analysis of the value of this meter, the number of methods of normalizing diagnostic variables within individual sub-methods was limited, taking for further research only those that provided an acceptable low value of $\mathrm{M}$ meter and gave the possibility to determine synthetic variables for all sub-methods. These methods turned out to be normalizations: Van Delft and Nijkamp, Weitendorf, Stopp and Voodg. The calculated values of the M measure for individual sub-methods are presented in Table 7.

The assessment of the impact of the method of standardization of diagnostic variables and the method of their ordering on the quality of facility rankings was based on the analysis of variance. The analysis also took into account the way of transforming destimulants into stimulants. The results of the analysis are presented in Table 8.

It shows that for all the analyzed methods, the method of variables normalization has no significant impact on the quality of ordering of regions. However, such an influence was observed in relation to the ordering method, and in the case of the SAW and SMD methods, also in relation to some stimulation methods of the destimulant.

The analysis of variance showed that the analyzed sub-methods can be divided into two groups which differ significantly in the quality of rank of facilities due to the level of sustainable energy. The sub-methods with significantly better rank quality are: SAW I, SAW II, SMD III, and all WASPAS sub-methods.

Effective linear object ordering consists not only of effective ranking of objects but also of their effective clustering. The best methods for clustering include methods with both small and large values of differences between the synthetic variables describing the objects. Small differences in distances between the objects indicate the presence of clusters with little differentiation in the degree of sustainable development of the energy sector. In turn, large distances between the ordered development indicators allow identifying clusters of objects with a different state of energy sustainability. 
Table 5. Raw diagnostic variables.

\begin{tabular}{|c|c|c|c|c|c|c|c|c|c|c|c|c|c|c|c|c|}
\hline \multirow{2}{*}{ Indicator } & \multicolumn{16}{|c|}{ Voivodeships-Regions * } \\
\hline & PL-DS & PL-KP & PL-LU & PL-LB & PL-LD & PL=MA & PL-MZ & PL-OP & PL-PK & PL-PD & PL-PM & PL-SL & PL-SK & PL-WP & PL-WN & PL-ZP \\
\hline$X_{1}$ & 806.0 & 755.4 & 691.6 & 773.9 & 826.5 & 833.3 & 932.9 & 835.4 & 596.5 & 796.1 & 780.2 & 807.6 & 640.1 & 722.9 & 815.9 & 730.0 \\
\hline$x_{2}$ & 9.4 & 9.7 & 14.8 & 9.8 & 8.8 & 8.5 & 7.3 & 13.0 & 13.3 & 13.2 & 10.2 & 6.1 & 8.9 & 10.9 & 10.5 & 7.0 \\
\hline$x_{3}$ & 70.4 & 79.5 & 32.6 & 83.1 & 286.0 & 43.2 & 108.5 & 180.1 & 43.1 & 32.5 & 48.5 & 91.3 & 203.1 & 29.3 & 77.5 & 130.8 \\
\hline $\mathrm{X}_{4}$ & 4.1 & 4.8 & 2.4 & 2.2 & 17.8 & 3.1 & 5.9 & 15.1 & 1.3 & 1.7 & 2.9 & 8.0 & 12.3 & 1.2 & 3.3 & 4.2 \\
\hline$X_{5}$ & $11,869.3$ & $18,613.7$ & $17,874.8$ & $13,851.0$ & $10,679.3$ & $15,741.4$ & $27,025.1$ & $66,097.6$ & 9808.9 & 7893.2 & $15,066.8$ & $33,274.8$ & $28,035.3$ & 8507.0 & 9680.1 & $21,312.6$ \\
\hline$x_{6}$ & 0.08 & 0.10 & 0.08 & 0.09 & 0.11 & 0.08 & 0.06 & 0.13 & 0.07 & 0.07 & 0.07 & 0.11 & 0.11 & 0.08 & 0.07 & 0.08 \\
\hline$X_{7}$ & 130.7 & 71.0 & 77.3 & 136.8 & 64.9 & 134.4 & 156.1 & 71.2 & 119.4 & 46.4 & 99.2 & 106.5 & 65.4 & 67.0 & 131.2 & 140.7 \\
\hline$X_{8}$ & 1.1 & 1.2 & 1.0 & 0.3 & 1.0 & 1.5 & 2.6 & 9.9 & 0.5 & 0.7 & 0.9 & 4.2 & 4.2 & 0.7 & 0.7 & 1.8 \\
\hline$X_{9}$ & 19.3 & 36.1 & 41.2 & 38.9 & 32.9 & 23.1 & 5.3 & 38.7 & 7.9 & 26.7 & 24.9 & 60.6 & 59.4 & 4.2 & 8.0 & 12.2 \\
\hline$X_{10}$ & 17.2 & 13.8 & 159.7 & 1.7 & 24.5 & 52.4 & 36.3 & 12.5 & 20.4 & 36.9 & 49.3 & 56.0 & 17.4 & 36.5 & 13.0 & 20.2 \\
\hline$x_{11}$ & 29.6 & 13.3 & 11.5 & 39.2 & 49.1 & 26.1 & 51.4 & 45.2 & 6.7 & 4.6 & 23.0 & 60.3 & 2.8 & 2.0 & 11.2 & 180.8 \\
\hline$X_{12}$ & 5.9 & 31.7 & 20.4 & 19.6 & 3.3 & 6.1 & 3.6 & 4.2 & 19.8 & 43.7 & 44.6 & 1.4 & 0.6 & 78.1 & 16.3 & 41.8 \\
\hline$x_{13}$ & 97.5 & 499.7 & 91.9 & 315.1 & 273.6 & 68.2 & 86.1 & 181.6 & 211.9 & 245.6 & 317.6 & 46.6 & 222.0 & 297.6 & 230.6 & 948.1 \\
\hline
\end{tabular}

Source: Local Data Bank, GUS. * PL-XX-abbreviation of the province name according to ISO 3166-2. 
Table 6. Basic characteristics of indicators describing regional sustainable energy development.

\begin{tabular}{cccccc}
\hline Indicator & Minimum & Maximum & Average & Coefficient of Variation & Character \\
\hline$X_{1}$ & 596.50 & 93,290 & 771.52 & 0.10 & Destimulant \\
\hline$X_{2}$ & 6.14 & 14.80 & 10.08 & 0.24 & Destimulant \\
\hline$X_{3}$ & 29.30 & 286.00 & 96.22 & 0.72 & Stimulant \\
\hline$X_{4}$ & 1.17 & 17.77 & 5.63 & 0.87 & Destimulant \\
\hline$X_{5}$ & 7893.20 & $66,097.61$ & $19,708.18$ & 0.73 & Destimulant \\
\hline$X_{6}$ & 0.06 & 0.13 & 0.09 & 0.23 & Destimulant \\
\hline$X_{7}$ & 46.44 & 156.13 & 101.14 & 0.34 & Stimulant \\
\hline$X_{8}$ & 0.32 & 9.85 & 2.02 & 0.65 & Destimulant \\
\hline$X_{9}$ & 4.23 & 60.65 & 27.46 & 1.04 & Stimulant \\
\hline$X_{10}$ & 1.74 & 159.72 & 35.48 & 1.25 & Stimulant \\
\hline$X_{11}$ & 2.00 & 180.82 & 34.80 & 0.86 & Stimulant \\
\hline$X_{12}$ & 0.61 & 78.13 & 21.31 & 0.82 & Stimulant \\
\hline$X_{13}$ & 46.57 & 948.15 & 258.35 & Stimulant \\
\hline
\end{tabular}

Table 7. Values of the aggregate measure of the quality of mapping diagnostic variables with synthetic variables.

\begin{tabular}{ccccc}
\hline Sub-Metod $\backslash$ Normalization & Van Delft and Nijkamp & Weitendorf & Stopp & Voddg \\
\hline SAW I & 2.43 & 1.98 & 2.18 & 2.41 \\
\hline SAW II & 2.36 & 1.98 & 2.06 & 2.40 \\
\hline SAW III & 2.22 & 1.93 & 2.18 & 2.40 \\
\hline TOPSIS I & 2.63 & 2.22 & 2.04 & 2.58 \\
\hline TOPSIS II & 2.30 & 2.07 & 2.10 & 2.44 \\
\hline TOPSIS III & 2.22 & 1.98 & 1.94 & 2.16 \\
\hline SMD I & 2.36 & 2.19 & 2.23 & 2.30 \\
\hline SMD II & 2.38 & 2.19 & 2.19 & 2.37 \\
\hline SMD III & 2.33 & 2.10 & 2.23 & 2.29 \\
\hline WASPAS I & 2.45 & 2.10 & 2.37 & 2.53 \\
\hline WASPAS II & 2.02 & 2.10 & 2.09 & 2.04 \\
\hline WASPAS III & 2.43 & 2.06 & 2.37 & 2.42 \\
\hline
\end{tabular}

In order to evaluate the analyzed methods in this respect, empirical distributions were developed, showing the frequency of distances between the objects, determined on the basis of the values of synthetic indicators.

For the SAW method (Figure 2), the percentage share of very small distances between synthetic variables is approximately $30 \%$, regardless of the normalization method and the method of conversion of diagnostic variables into stimulants.

Nevertheless, the normalization method has an impact on the occurrence of greater value differences. For Voodg's normalization method, large differences between the examined objects were rarely observed, and their share was below 0.02. In light of the adopted evaluation criteria, this normalization cannot be used for determining clusters of objects with the use of the SAW method. 
Table 8. Results of the analysis of variance in the evaluation of ranking quality.

\begin{tabular}{|c|c|c|}
\hline \multirow{2}{*}{ Linear Ordering Sub-Method * } & \multicolumn{2}{|c|}{ Ranking Quality Measure $u_{p}{ }^{* *}$} \\
\hline & Value Range & Mean Value \\
\hline 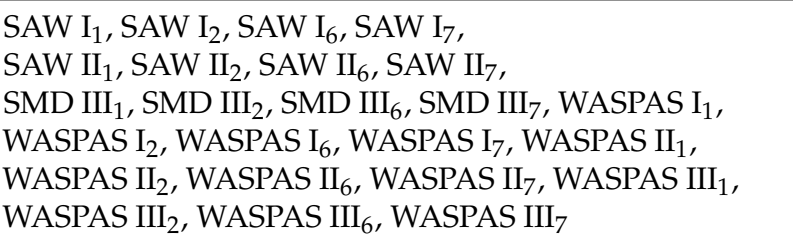 & $0.78-0.88$ & 0.84 \\
\hline 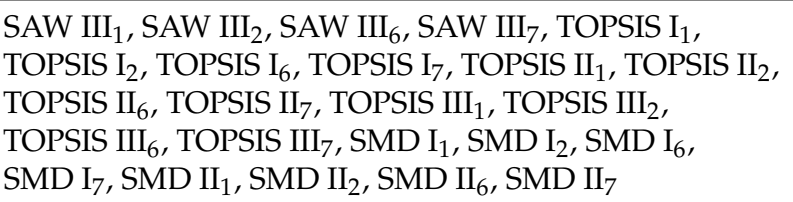 & $0.64-0.84$ & 0.77 \\
\hline
\end{tabular}
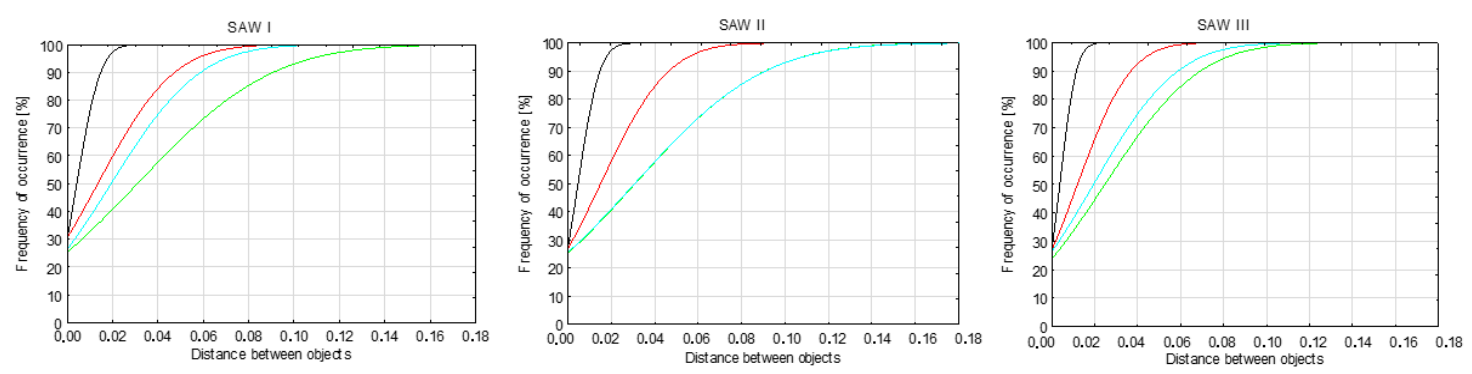

- Van Delft and Nijkamp normalization, - Weitendorf normalization,

- Stopp normalization, - Voodg normalization.

Figure 2. Empirical distributions of frequency of distances between the objects for the SAW method.

The largest differences between 0.10 and 0.18 were observed for Weitendorf's normalization method, in relation to all sub-methods, and for Stopp's normalization method in relation to the SAW II and SAW III sub-methods.

Using the WASPAS method for the initial conversion of diagnostic variables, similar regularities were observed as for the SAW method (Figure 3). The percentage share of the smallest differences between synthetic variables for all normalization methods was at the level of $30 \%$ while obtaining differences with values above 0.1 for a minimum of $10 \%$ of observations was ensured by Weitendorf's normalization method.
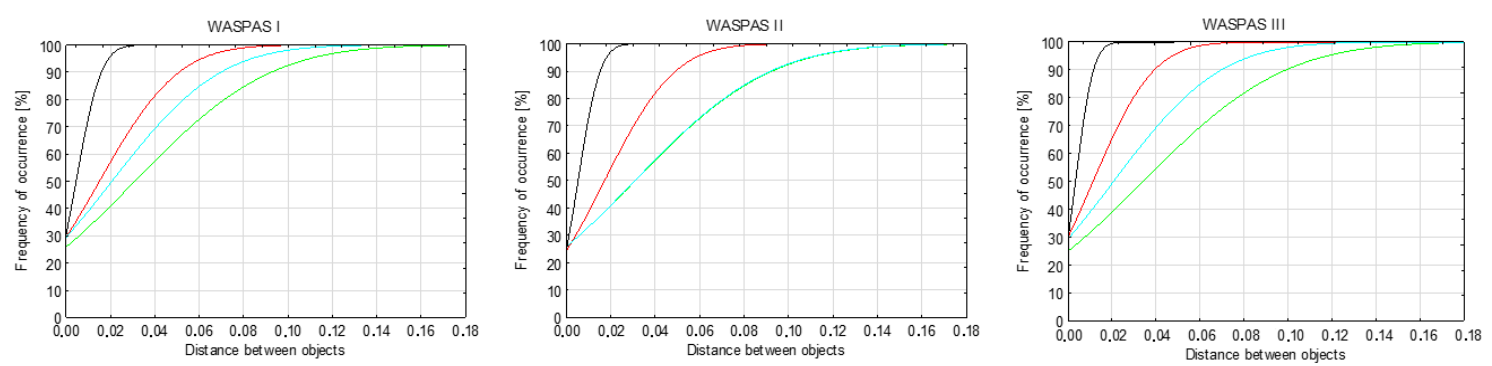

Figure 3. Empirical distributions of frequency of distances between the objects for the WASPAS method. Empirical distributions markings as in the Figure 2. 
For other methods, a slight impact of the normalization method of decision variables was observed on the level of differences between the objects ordered in a non-increasing manner in relation to the synthetic variable (Figures 4 and 5). It can, therefore, be assumed that these methods allow us to obtain very good results in terms of the determination of object clusters for the majority of the tested variants of preliminary processing of diagnostic variables.
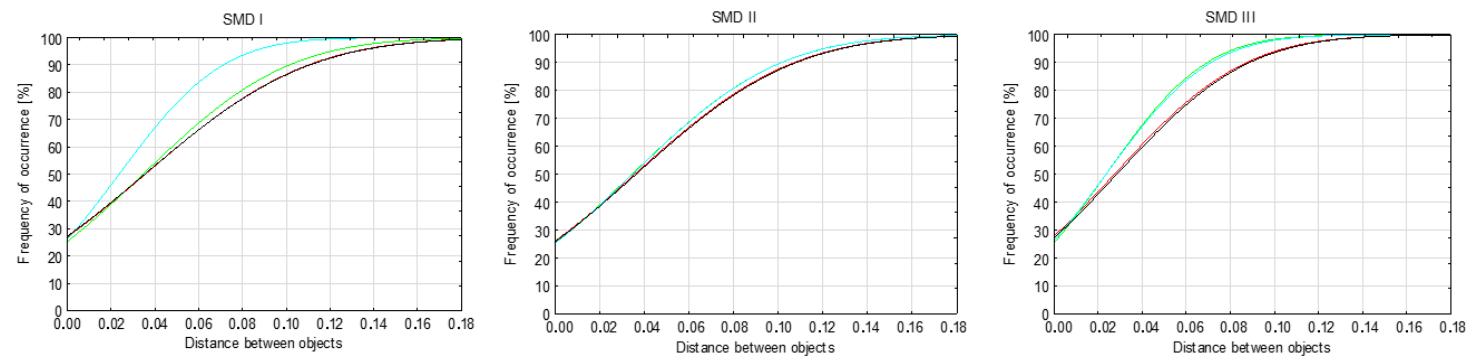

Figure 4. Empirical distributions of the frequency of distance between objects for the Hellwig method. Empirical distributions markings as in Figure 2.
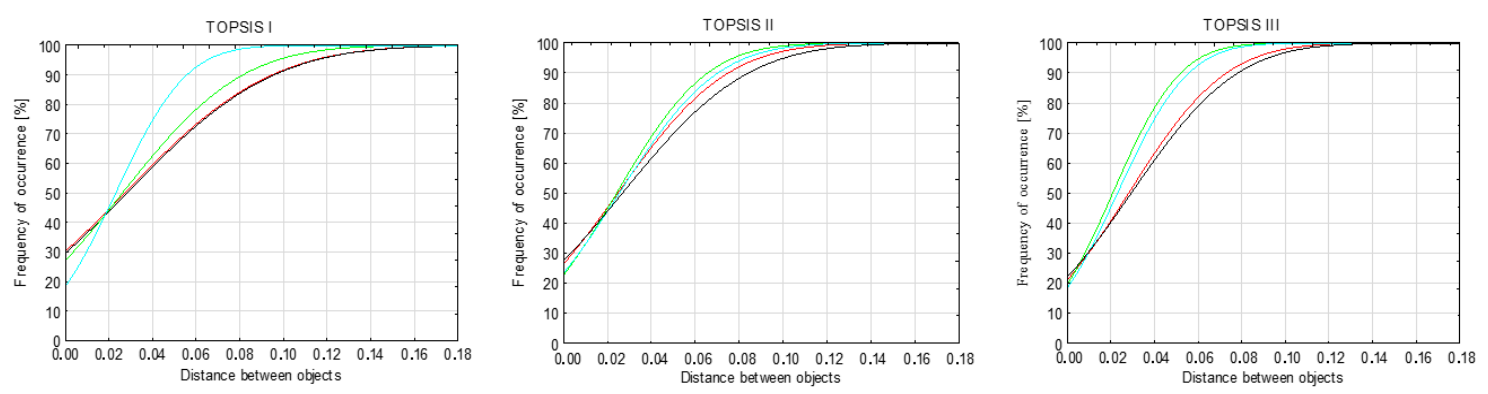

Figure 5. Empirical distributions of the frequency of distance between objects for the TOPSIS method. Empirical distributions markings as in Figure 2.

The conducted analysis did not explicitly indicate the best sub-method and normalization of diagnostic variables for the purposes of the linear ordering of regions with regard to the degree of energy sustainability. However, what it did indicate were the more preferable methods.

Among the preferable methods, the SMD III sub-method was selected with Weitendorf's normalization formula, which is characterized by the highest value of the ranking quality measure $\left(u_{p}=0.88\right)$ and effective clustering of objects.

\subsection{Sensitivity Analysis}

In order to confirm the usefulness of the proposed procedure for the selection of an effective method of ranking and aggregation of variables for the assessment of energy sustainability, a sensitivity analysis was conducted. It consists of examining the impact of changes in parameters on the obtained solution and assessing its stability. The study examined the sensitivity of decision-making solutions for grouping regions into development types to changes in the values of the adopted criteria. For this purpose, a simulation study was conducted, consisting of changing the values of individual diagnostic variables in the range $+/-10 \%$ of their value, considered an error acceptable in public statistics. For example, using the methods considered to be more effective in the ranking of objects (Table 8), using Weitendorf's normalization, it was found that the share of objects that changed their development types did not exceed $8 \%$. For the other methods with Voogd's normalization, this share was 16\%. The sensitivity analysis allowed us to conclude that the procedure proposed in the paper gives a relatively stable solution to the problem. 


\subsection{Analysis of Sustainable Energy Development of Polish Regions}

The developed procedure is designed to assist policy-makers at a national and regional level in making sustainable energy decisions based on the MCDM methodology. So far, sustainability assessments, including energy assessments at a regional level, have in most cases been carried out by experts who assess progress in meeting EU and national requirements on the basis of individual indicators.

The implementation of the developed procedure has been presented on the example of the assessment of the degree of energy sustainability of Polish regions, at the level of provinces, in the social, economic, and ecological dimension, using the SMD III method with the Weitendorf's normalization formula.

The evaluation was based on a statistical criterion using the arithmetic mean and standard deviation of synthetic indicators, each time dividing the provinces into 4 classes representing high (class I), higher average (class II), lower average (class III), and low (class IV) level of sustainable energy development.

Results of the calculations are shown in Figure 6. The figures show the position of a given region in the ranking within individual dimensions. What can be observed are differences in ranks, and in the case of the four provinces each time they display different development types.
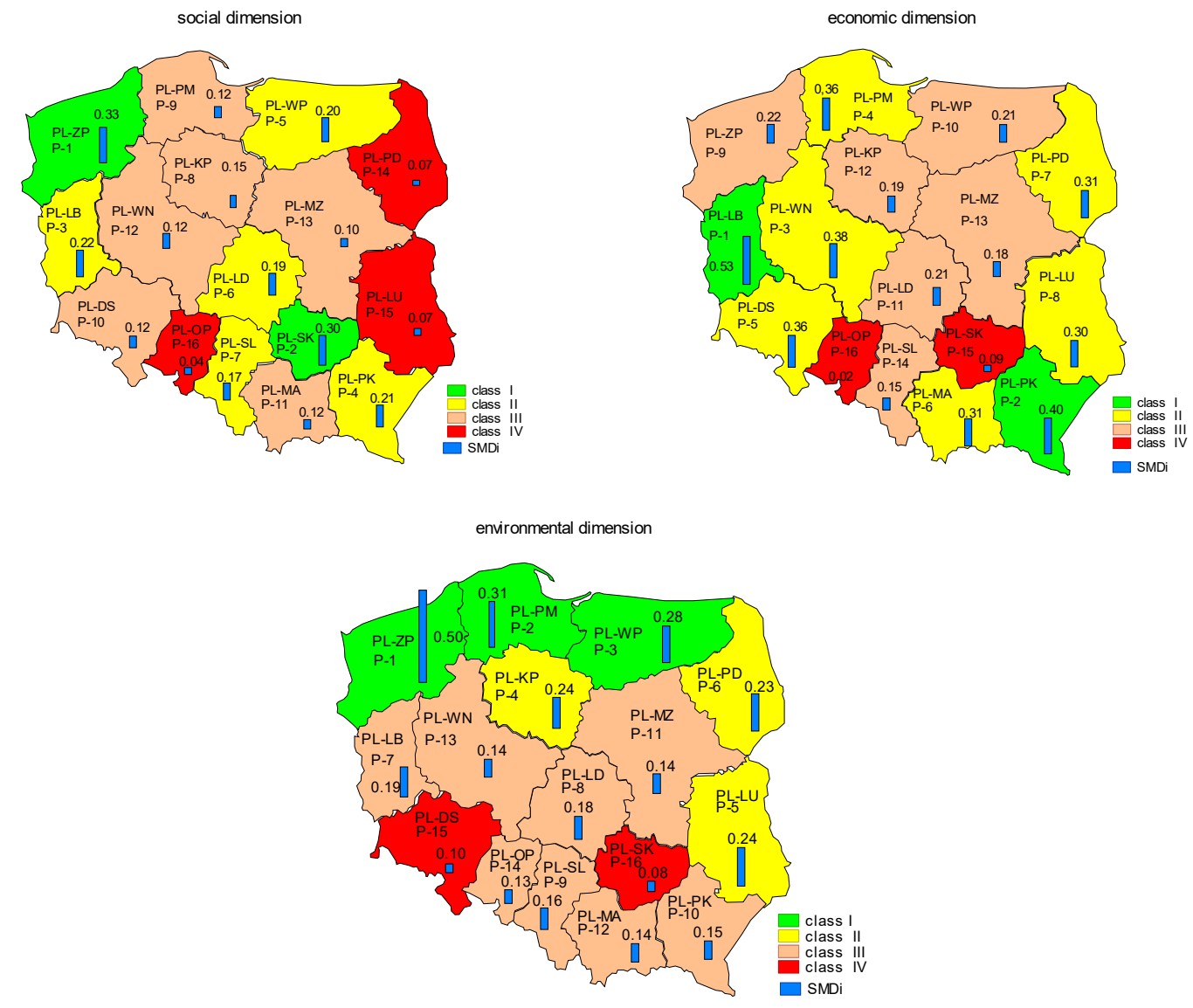

Figure 6. The state of sustainable energy development in Poland at the provincial level in the social, economic, and environmental dimensions.

Where: P-X-position of the voivodship in the ranking $(X=1$-the highest level of suistainable development, $X=16$-the lovest level of suistainable development, SMDi-value of the synthetic indicator of sustainable energy development. 
The analysis of sustainable energy development in terms of the social, economic, and environmental dimensions shows that most voivodeships are characterized by an average level of energy sustainability. A low level of energy sustainability in the social dimension occurs in the areas of Eastern Poland. These areas are among the poorest in Poland. Farms in this area are characterized by low income, and the security of electricity supply is one of the lowest in the country.

The northern regions of Poland are undoubtedly the leaders in the environmental dimension. The zachodniopomorskie voivodeship (PL-ZP) stands out in particular due to the considerable use of renewable energy sources and high expenditure on reducing pollution. This region should serve as a model of energy sustainability for other parts of Poland in terms of the environmental dimension.

The results on energy sustainability at the voivodeship level can be compared with the results for the entire country, assessing whether the European Union's requirements for sustainable energy development are met in Poland. In recent years, Poland has managed to increase its GDP sevenfold and, at the same time, reduce emissions of pollutants from the energy and heating sectors by $30 \%$ in relation to 1989. At the same time, between 2000 and 2016, the share of RESs and natural gas in electricity production increased fivefold, and the share of coal decreased by 12 percentage points [84]. However, everything points to the fact that in the perspective of 2030, greenhouse gas emissions in Poland will fall by only $30 \%$, compared to the required $40 \%$, if no action is taken in the regions to reduce coal consumption in the power and heating sectors.

\section{Conclusions}

While conducting research of multi-feature objects, such as the research presented in this paper on regions in terms of the degree of sustainable energy development, appropriate selection of diagnostic indicators is of primary importance. The substantive selection of indicators describing regional energy sustainability is limited by the availability of relevant data in public statistics. The sets of published indicators change over time, making comparisons difficult. In addition, the published indicators are largely highly correlated with one another, also their usefulness for evaluating sustainability is often questionable.

A more feasible option is attempting to improve the quality of research results of multi-feature objects by optimizing research methods and procedures. Such an attempt was made in this paper for the process of linear ordering of regions with regard to the level of energy sustainability.

For that purpose, a procedure for selecting the method of the linear ordering of multi-feature objects was developed, which enabled the selection of not only the ordering method and normalization formulas but also the methods of conversion of destimulants into stimulants. The usefulness of the procedure developed, especially for grouping regions into development types, has been confirmed by the sensitivity analysis of decision-making solutions to changes in the values of the criteria adopted.

This procedure can be successfully used for ordering objects at other levels than the regional one and for analyzing sustainable development in terms of aspects other than energy.

The practical application of the developed procedure was demonstrated on the example of the evaluation of sustainable energy development of Polish regions

It was found that most of the regions are characterized by the average level of energy sustainability in the social, economic, and environmental dimensions.

The work focuses on the problems of evaluating energy sustainability at a regional level to assist policy-makers. For this purpose, a linear ordering method was used, which is relatively simple but not without disadvantages. When using linear ordering to rank the objects, there are problems with the interpretation of the distance and thus the obtained research results. The reliability of the obtained results is further reduced by the fact that MCDM methods are often based on uncertain input data. In order to obtain more reliable results, this uncertainty should be taken into account by replacing linear rankings with probabilistic rankings. The authors intend to take into account the probability distribution of the individual criteria in further research on energy sustainability. 
Author Contributions: Conceptualization, M.T.; software, M.T. and K.N.; data curation, K.N.; investigation, M.T. and K.N.; methodology, M.T. and K.N.; project administration, K.N.; supervision, M.T.; writing一original draft, M.T. and K.N.; writing-reviewing and editing, M.T. and K.N. All authors have read and agreed to the published version of the manuscript.

Funding: This research was financed by the Ministry of Science and Higher Education of the Republic of Poland.

Conflicts of Interest: The authors declare no conflict of interest.

\section{References}

1. 2030 Climate \& Energy Framework. Available online: https://ec.europa.eu/clima/policies/strategies/2030_en (accessed on 20 October 2020).

2. International Atomic Energy Association. Energy Indicators for Sustainable Development; Guidel Methodol: Vienna, Austria, 2005.

3. Sustainable Development Goals-Overview. Available online: https://ec.europa.eu/eurostat/web/sdi/overview (accessed on 20 May 2020).

4. International Energy Agency; World Energy Balances: Paris, France, 2011.

5. Renewables 2020 Global Status Report-REN21. Available online: https:/www.google.com/url?sa=t\&rct=j\& $\mathrm{q}=\&$ esrc=s\&source=web\&cd=\&ved=2ahUKEwiipM7ykcrsAhWClYsKHRTzCGAQFjAFegQIBBAC\&url =https $\% 3 \mathrm{~A} \% 2 \mathrm{~F} \% 2 \mathrm{Fwww} \cdot$ ren21.net $\% 2 \mathrm{Fwp}$-content $\% 2$ Fuploads $\% 2 F 2019 \% 2 \mathrm{~F} 05 \% 2 \mathrm{Fgsr}$ 2020_full_report _en.pdf\&usg=AOvVaw3KeCM-CpcTK3QnR0z9WClm (accessed on 20 October 2020).

6. Global Energy Transformation a Roadmap to 2050. Available online: https://www.google.com/url?sa=t\&rct= $\mathrm{j} \& \mathrm{q}=\&$ esrc $=$ s\&source=web\&cd=\&ved=2ahUKEwioxeTLksrsAhUmxosKHXrhBFgQFjADegQIAxAC\&url =https $\% 3 \mathrm{~A} \% 2 \mathrm{~F} \% 2 \mathrm{Fwww}$.teraz-srodowisko.pl\%2Fmedia\%2Fpdf\%2Faktualnosci\%2F6741-IRENA-global -energy-transformation-2019.pdf\&usg=AOvVaw0XIiC1ZcGEq8dpEjourLEw (accessed on 20 October 2020).

7. Razmjoo, A.A.; Sumper, A.; Davarpanah, A. Development of sustainable Energy indexes by the utilization of new indicators: A comparative study. Energy Rep. 2019, 5, 375-383. [CrossRef]

8. Graczyk, A. Wskaźniki zrównoważonego rozwoju energetyki. Optimum. Studia Ekon. 2017, 4, 53-68. [CrossRef]

9. Commission Regulation (EU) No 431/2014 of 24 April 2014 Amending Regulation (EC) No 1099/2008 of the European Parliament and of the Council on Energy Statistics as Regards the Implementation of Annual Statistics on Energy Consumption in Households, OJ L 131/1. Available online: https://eur-lex.europa.eu/le gal-content/en/ALL/?uri=CELEX\%3A32014R0431 (accessed on 30 May 2020).

10. Iddrisu, I.; Bhattacharyya, S.C. Sustainable Energy Development Index: A multi-dimensional indicator for measuring sustainable energy development. Renew. Sustain. Energy Rev. 2015, 50, 513-530. [CrossRef]

11. Patlitzianas, K.D.; Doukas, H.; Kagiannas, A.G.; Psarras, J. Sustainable energy policy indicators: Review and recommendations. Renew. Energy 2008, 33, 966-973. [CrossRef]

12. Gunnarsdottir, I.; Davidsdottir, B.; Worrelll, E.; Sigurgeirsdottir, S. Review of indicators for sustainable energy development. Renew. Sustain. Energy Rev. 2020, 133, 110294. [CrossRef]

13. Cosmi, C.; Dvarionienè, J.; Marques, I.; Di Leo, S.; Gecevičius, G.; Gurauskienè, I.; Mendes, G.; Selada, C. A Holistic approach to sustainable energy development at regional level: The RENERGY self-assessment methodology. Renew. Sustain. Energy Rev. 2015, 49, 693-707. [CrossRef]

14. Fouché, E.; Brent, A. Explore, design and act for sustainability: A participatory planning approach for local energy sustainability. Sustainability 2020, 12, 862. [CrossRef]

15. Ghenai, C.; Albawab, M.; Bettayeb, M. Sustainability indicators for renewable energy systems using multi-criteria decision-making model and extended SWARA/ARAS hybrid method. Renew. Energy 2020, 146, 580-597. [CrossRef]

16. Trojanowska, M.; Nęcka, K. Multi-dimensional comparative analysis of renewable energy sources development. In Renewable Energy Sources: Engineering, Technology, Innovation ICORES; Springer: Berlin/Heidelberg, Germany, 2018; pp. 1025-1034.

17. Narula, K.; Reddy, S. A SES (sustainable energy security) index for developing countries. Energy 2016, 94, 326-343. [CrossRef]

18. Mirjat, N.H.; Uqaili, M.A.; Harijan, K.; Mustafa, M.W.; Rahman, M.; Khan, W.A. Multi-criteria analysis of electricity generation scenarios for sustainable energy planningin Pakistan. Energies 2018, 11, 757. [CrossRef] 
19. Siksnelyte, I.; Zavadskas, E.K.; Streimikiene, D.; Sharma, D. An overview of multi-criteria decision-making methods in dealing with sustainable energy development issues. Energies 2018, 11, 2754. [CrossRef]

20. Jiang-Jiang, W.; You-Yin, J.; Chun-Fa, Z.; Jun-Hong, Z. Review on multi-criteria decision analysis aid in sustainable Energy decision-making. Renew. Sustain. Energy Rev. 2009, 13, 2263-2278.

21. Siksnelyte-Butkiene, I.; Zavadskas, E.K.; Streimikiene, D. Multi-Criteria Decision-Making (MCDM) for the Assessment of Renewable Energy Technologies in a Household: A Review. Energies 2020, 13, 1164. [CrossRef]

22. Jahan, A.; Edwards, K.L. A state-of-the-art survey on the influence of normalization techniques in ranking: Improving the materials selection process in engineering design. Mater. Des. 2015, 65, 335-342. [CrossRef]

23. Chakraborty, S.; Yeh, C.H. A simulation based comparative study of normalization procedures in multiattribute decision making. In Proceedings of the 6th WSEAS International Conference on Artificial Intelligence, Knowledge Engineering and Data Bases, Corfu Island, Greece, 16-19 February 2007.

24. Vafaei, N.; Ribeiro, R.A.; Camarinha-Matos, L.M. Selection of Normalization Technique for Weighted Average Multi-criteria Decision Making. In Technological Innovation for Resilient Systems. DoCEIS 2018. IFIP Advances in Information and Communication Technology; Camarinha-Matos, L., Adu-Kankam, K., Julashokri, M., Eds.; Springer: Cham, Switzerland, 2018; Volume 521, pp. 43-52. [CrossRef]

25. Celen, A. Comparative Analysis of Normalization Procedures in TOPSIS Method: With an Application to Turkish Deposit Banking Market. Informatica 2014, 25, 185-208. [CrossRef]

26. Vafaei, N.; Ribeiro, R.A.; Camarinha-Matos, L.M. Data normalisation techniques in decision making: Case study with TOPSIS method. Int. J. Inf. Decis. Sci. 2018, 10, 19-38. [CrossRef]

27. Vafaei, N.; Ribeiro, R.A.; Camarinha-Matos, L.M. Selecting Normalization Techniques for the Analytical Hierarchy Process. In Technological Innovation for Life Improvement. DoCEIS 2020. IFIP Advances in Information and Communication Technology; Springer: Cham, Switzerland, 2020; Volume 577. [CrossRef]

28. Chatterjee, P.; Chakraborty, S. Investigating the Effect of Normalization Norms in Flexible Manufacturing Sytem Selection Using Multi-Criteria Decision-Making Methods. J. Eng. Sci. Technol. Rev. 2014, 7, 141-150. [CrossRef]

29. Zaidan, B.B.; Zaidan, A.A. Comparative study on the evaluation and benchmarking information hiding approaches based multi-measurement analysis using TOPSIS method with different normalisation, separation and context techniques. Measurement 2018, 117, 277-294. [CrossRef]

30. Pavličić, D.M. Normalization affects the results of MADM methods. Yugosl. J. Oper. Res. 2011, 11, $251-265$.

31. Więckowski, J.; Sałabun, W. How the normalization of the decision matrix influences the results in the VIKOR method? Procedia Comput. Sci. 2020, 176, 2222-2231. [CrossRef]

32. Jain, S.; Shukla, S.; Wadhvani, R. Dynamic selection of normalization techniques using data complexity measures. Expert Syst. Appl. 2018, 106, 252-262. [CrossRef]

33. Opricovic, S.; Tzeng, G.-H. Compromise solution by MCDM methods: A comparative analysis of VIKOR and TOPSIS. Eur. J. Oper. Res. 2004, 156, 445-455. [CrossRef]

34. Papathanasiou, J.; Ploskas, N.; Bournaris, T.; Manos, B. A Decision Support System for Multiple Criteria Alternative Ranking Using TOPSIS and VIKOR: A Case Study on Social Sustainability in Agriculture; Liu, S., Delibašić, B., Oderanti, F., Eds.; ICDSST, LNBIP, Springer: Cham, Switzerland, 2016; Volume 250, pp. 3-15. [CrossRef]

35. Bak, A. Comparative analysis of selected linear ordering methods based on empirical and simulation data. Res. Pap. Wroctaw Univ. Econ. 2018, 508, 20-28. [CrossRef]

36. Grabiński, T.; Wydymus, S.; Zeliaś, A. Metody Taksonomii Numerycznej w Modelowaniu Zjawisk SpołecznoGospodarczych; PWN: Warszawa, Poland, 1989.

37. Roszko-Wójtowicz, E.; Grzelak, M.M. The Use of Selected Methods of Linear Ordering to Assess the Innovation Performance of the European Union Member States, ISSN paper version 1642-2597 ISSN electronic version 2081-8319. Econ. Environ. Stud. 2019, 19, 9-30. [CrossRef]

38. Ceballos, B.; Lamata, M.T.; Pelta, D.A. A comparative analysis of multi-criteria decision-making methods. Prog. Artif. Intell. 2016, 5, 315-322. [CrossRef]

39. Wang, J.-J.; Zhang, C.-F.; Jing, Y.-Y.; Zheng, G.-Z. Using the fuzzy multi-criteria model to select the optimal cool storage system for air conditioning. Energy Build. 2008, 40, 2059-2066. [CrossRef]

40. Wang, J.-J.; Jing, Y.-Y.; Zhang, C.-F.; Zhang, X.-T.; Shi, G.-H. Integrated evaluation of distributed triple-generation systems using improved grey incidence approach. Energy 2008, 33, 1427-1437. [CrossRef] 
41. Madlener, R.; Kowalski, K.; Stagl, S. New ways for the integrated appraisal of national energy scenarios: The case of renewable energy use in Austria. Energy Policy 2007, 35, 6060-6074. [CrossRef]

42. Begic, F.; Afgan, N.H. Sustainability assessment tool for the decision making in selection of energy system-Bosnian case. Energy 2007, 32, 1979-1985. [CrossRef]

43. Afgan, N.H.; Carvalho, M.G. Multi-criteria assessment of new and renewable energy power plants. Energy 2002, 27, 739-755. [CrossRef]

44. Pilavachi, P.A.; Stephanidis, S.D.; Pappas, V.A.; Afgan, N.H. Multi-criteria evaluation of hydrogen and natural gas fuelled power plant technologies. Appl. Therm. Eng. 2009, 29, 2228-2234. [CrossRef]

45. Gershon, M. Model Choice in Multi-Objective Decision-Making in Natural Resource Systems. Ph.D. Thesis, University of Arizona, Tucson, AZ, USA, 1981.

46. Tecle, A. Choice of Multi-Criteria Decision-Making Techniques for Watershed Management. Ph.D. Thesis, University of Arizona, Tucson, AZ, USA, 1988.

47. Trzaskalik, T. Wielokryterialne wspomaganie decyzji. Przegląd metod i zastosowań. Zesz. Nauk. Organ. i Zarzadzanie Politech. Ślaska 2014, 2014, 239-263.

48. Maghsoodi, A.I.; Kavian, A.; Khalilzadeh, M.; Brauers, W.K.M. CLUS-MCDA: A novel framework based on cluster analysis and multiple criteria decision theory in a supplier selection problem. Comput. Ind. Eng. 2018, 118, 409-422. [CrossRef]

49. Singh, R.K.; Murty, H.R.; Gupta, S.K.; Dikshit, A.K. An overview of sustainability assessment methodologies. Ecol. Indic. 2009, 9, 189-212. [CrossRef]

50. Troldborg, M.; Heslop, S.; Hough, R.L. Assessing the sustainability of renewable energy technologies using multi-criteria analysis: Suitability of approach for national-scale assessments and associated uncertainties. Renew. Sustain. Energy Rev. 2014, 39, 1173-1184. [CrossRef]

51. Bolcárová, P.; Kološta, S. Assessment of sustainable development in the EU 27 using aggregated SD index. Ecol. Indic. 2015, 48, 699-705. [CrossRef]

52. Lazar, N.; Chithra, K. A comprehensive literature review on development of Building Sustainability Assessment Systems. J. Build. Eng. 2020, 32, 101450. [CrossRef]

53. Atabaki, M.S.; Aryanpur, V. Multi-objective optimization for sustainable development of the power sector: An economic, environmental, and social analysis of Iran. Energy 2018, 161, 493-507. [CrossRef]

54. Li, T.; Li, A.; Guo, X. The sustainable development-oriented development and utilization of renewable energy industry-A comprehensive analysis of MCDM methods. Energy 2020, 212, 118694. [CrossRef]

55. Siksnelyte, I.; Zavadskas, E.K.; Bausys, R.; Streimikiene, D. Implementation of EU energy policy priorities in the Baltic Sea Region countries: Sustainability assessment based on neutrosophic MULTIMOORA method. Energy Policy 2019, 125, 90-102. [CrossRef]

56. Olson, D.L. Comparison of three multicriteria methods to predict know outcomes. Eur. J. Oper. Res. 2001, 130, 576-587. [CrossRef]

57. Kukuła, K.; Luty, L. Jeszcze o procedurze wyboru metody porządkowania liniowego. Przeglad Stat. 2017, 64, 163-176. [CrossRef]

58. Debkowska, K.; Jarocka, M. The impact of the methods of the data normalization on the result of linear ordering. Acta Univ. Lodz. Folia Oeconomica 2013, 286, 181-188.

59. Drabarczyk, K. Zrównoważony rozwój województw-Analiza porównawcza. Zesz. Nauk. Politech. Częstochowskiej Zarządzanie 2017, 25, 23-34. [CrossRef]

60. Müller-Frączek, I. Propozycja miary syntetycznej. Przegląd Stat. 2017, LXIV, 421-436.

61. Kukuła, K.; Luty, L. Propozycja procedury wspomagającej wybór metody porządkowania liniowego. Przegląd Stat. 2015, 62, 219-231.

62. Altintas, K.; Vayvay, O.; Apak, S.; Cobanoglu, E. An extended GRA method integrated with fuzzy AHP to construct a multidimensional index for ranking overall energy sustainability. Sustainability 2020, 12, 1602. [CrossRef]

63. Yi, P.; Lu Wang, L.; Zhang, D.; Li, W. Sustainability Assessment of Provincial-Level Regions in China Using Composite Sustainable Indicator. Sustainability 2019, 11, 5289. [CrossRef]

64. Li, S.; Li, R. Energy sustainability evaluation model based on the matter-element extension method: A case study of shandong province, China. Sustainability 2017, 9, 2128. [CrossRef] 
65. Zhouab, X.; Zhanga, R.; Yanga, K.; Yanga, C.; Huangc, T. Using hybrid normalization technique and state transition algorithm to VIKOR method for influence maximization problem. Neurocomputing 2020, 410, 41-50. [CrossRef]

66. Central Statistical Office. Local Data Bank. Available online: http://stat.gov.pl/bdl/app/strona.html?p_name =indeks (accessed on 20 June 2020).

67. Van Delft, A.; Nijkamp, P. Multi-Criteria Analysis and Regional Decision-Making; M. Nijhoff: Leiden, The Netherlands, 1977.

68. Weitendorf, D. Beitrag zur optimierung der räumlichen Struktur eines Gebäude; Dissertation A an der Architektur und Bauwesen Fakultät der Bauhaus-Universität: Weimar, Germany, 1976.

69. Peldschus, F. Zur Anwendung der Theorie der Spiele für Aufgaben der Bautechnologie; Dissertation B: Leipzig, Germany, 1986.

70. Jüttler, H. Untersuchungen zur Fragen der Operationsforschung und ihrer Anwendungsmöglichkeiten auf Ökonomische Problemstellungen unter Besonderer Berücksichtigung der Spieltheorie; Dissertation A an der Wirtschaftswissenschaftlichen Fakultät der Humboldt-Universität: Berlin, Germany, 1966.

71. Körth, H. Untersuchungen zur Nichtlinearen Optimierung Ökonomischer Erscheinungen und Prozesse unter Besonderer Berücksichtigung der Quotientenoptimierung sowie der Lösung Ökonomischer Mathematischer Modelle bei Existenz Mehrerer Zielfuntionen; Habilitationsschrift Humboldt-Universität Sektion Wirtschaftswissenschaften: Berlin, Germany, 1969.

72. Stopp, F. Variantenvergleich Durch Matrixspiele; Wissenschaftliche Zeitschrift der Hochschule für Bauwesen: Leipzig, Germany, 1975.

73. Voogd, H. Multicriteria Evaluation for Urban and Regional Planning; Pion Ltd.: London, UK, 1983.

74. Zavadskas, E.K.; Turskis, Z. A new logarithmic normalization method in games theory. Informatica 2008, 19, 303-314. [CrossRef]

75. Churchman, C.W.; Ackoff, R.L. An approximate measure o value. J. Oper. Res. Soc. Am. 1954, 2, $172-187$. [CrossRef]

76. Hwang, C.L.; Yoon, K. Multiple Attribute Decision Making: Methods and Applications; Springer: New York, NY, USA, 1981.

77. Yoon, K.; Hwang, C.L. Multiple Attribute Decision Making: An Introduction; Sage Publications: Thousand Oaks, CA, USA, 1995.

78. Hellwig, Z. Zastosowanie metody taksonomicznej do typologicznego podziału krajów ze względu na poziom ich rozwoju oraz zasoby i strukturę wykwalifikowanych kadr. Przeglą Stat. 1968, 4, 307-327.

79. Zavadskas, E.K.; Turskis, Z.; Antucheviciene, J.; Zakarevicius, A. Optimization of weighted aggregated sum product assessment. Elektron. Elektrotechnika Electron. Electr. Eng. 2012, 122, 3-6. [CrossRef]

80. Kemmler, A.; Spreng, D. Energy indicators for tracking sustainability in developing countries. Energy Policy 2007, 35, 2466-2480. [CrossRef]

81. Vera, I.A.; Langlois, L.M.; Rogner, H.H.; Jalal, A.I.; Toth, F.L. Indicators for sustainable energy development: An initiative by the International Atomic Energy Agency. Nat. Resour. Forum 2005, 29, 274-283. [CrossRef]

82. Liu, G. Development of a general sustainability indicator for renewable energy systems: A review. Renew. Sustain. Energy Rev. 2014, 31, 611-621. [CrossRef]

83. Shaaban, M.; Scheffran, J. Selection of sustainable development indicators for the assessment of electricity production in Egypt. Sustain. Energy Technol. Assess. 2017, 22, 65-73. [CrossRef]

84. Polityka Energetyczna Polski do 2040 Roku (PEP2040); Ministerstwo Energii: Warszawa, Poland, 2019. Available online: https://www.gov.pl/web/aktywa-panstwowe/zaktualizowany-projekt-polityki-energetycznej-pols ki-do-2040-r (accessed on 20 May 2020).

Publisher's Note: MDPI stays neutral with regard to jurisdictional claims in published maps and institutional affiliations. 